\title{
Emergency palliative care planning and support in a COVID-19 pandemic
}

The current COVID-19 pandemic is straining on our palliative care resources. Much of COVID-19 is about symptom control for all patients, supporting families in crises, decision support in the face of uncertainty, and providing psychosocial and spiritual support. Due to the surge of COVID-19 cases, we had to optimize palliative care provision beyond our specialist service. In addition, setting up a responsive hospital-based palliative care service in liaison with community services has become crucial as we approach the peak of this pandemic. Our approach is based on the following domains:

\section{Developing service capacity}

- Promoting a palliative care approach among generalists through short and focused teaching and training. The teaching comprised symptom management, principles of palliative care and communication techniques; including 'what to say' and 'how to say it' remotely, and in different contexts

- Developing and sharing guidance on managing symptoms in COVID-19 that can be used by clinicians in all areas of acute settings. The guidance is aimed at allowing clinicians to manage common symptoms in COVID-19 effectively for all patients; including, dyspnea, pain, agitation, and delirium.

- Planning the service closely in collaboration with community teams and local hospices. Weekly virtual meetings with community partners are held to plan and allocate scarce resources, and develop innovative ways of stocking medications; while preparing for using alternative routes for managing symptoms in the community, where availability is limited [table 1].

- Creating an expedited process for discharging patients who can be cared for at home through partnership working with community teams and community palliative care services, and by working closely with the emergency and intensive care teams

- Creating a support system for healthcare professionals who are dealing with family crises, and death and dying to prevent burnout

\section{Educating the generalist workforce}

- Providing a group $15 \mathrm{~min}$ face-to-face teaching, alongside teaching at the bedside while providing palliative care consultation

- Developing and sharing guidance on communication and breaking difficult news, remotely and face-to-face, for patients and family caregivers in the context of 'screening', 'place of care', 'admitting', 'deciding', 'counselling', 'resourcing', 'anticipating', and 'grieving' ${ }^{\text {i }}$

- Leading on promoting advance care planning in a way that can be shared with all healthcare professionals that might get involved in providing care in different settings, including ambulance services. It became essential to support community services to have discussions with all older and frail people around their goals of care, ensuring that their advance care plans are updated 


\section{Care of family caregivers}

- Supporting caregivers in limited or absent visiting opportunities to the hospital through remote contact and support, and helping patients connect with family members though the use of technology. Many redeployed healthcare professionals and volunteers can be a valuable resource in providing this type of support alongside the chaplaincy teams.

- Empowering family caregivers to play an active role in providing care has become essential as we get closer to the peak of this pandemic. This includes teaching family caregivers to give subcutaneous medications to manage symptoms in the community, and enable them to manage care with remote advice and support from community and palliative care services, where appropriate.

Table 1 -Symptom control in the community at the end of life in a COVID-19 pandemic

\begin{tabular}{|c|c|c|c|}
\hline Symptom & Oral route & Sublingual/buccal route & Subcutaneous route \\
\hline Pain & $\begin{array}{l}\text { Morphine sulphate IR } 2.5-5 \mathrm{mg} \\
\text { PRN and titrate if opioid naïve } \\
\text { Morphine sulphate MR } 5-10 \mathrm{mg} \\
\text { BD as a start and titrate as } \\
\text { required }\end{array}$ & $\begin{array}{l}\text { Concentrated morphine } \\
\text { sulphate } 20 \mathrm{mg} / \mathrm{ml} \text { oral } \\
\text { solution } 2-5 \mathrm{mg}(0.1-0.25 \mathrm{ml}) \\
\text { PRN. Apply buccally and rub } \\
\text { into cheek to take effect }\end{array}$ & $\begin{array}{l}\text { Morphine sulphate } 2.5 \text { - } \\
\text { 5mg PRN }\end{array}$ \\
\hline Dyspnea & $\begin{array}{l}\text { Morphine sulphate } 10 \mathrm{mg} / 5 \mathrm{ml} \\
\text { solution } 2.5-5 \mathrm{mg} \text { PRN hourly and } \\
\text { titrate if opioid naive }\end{array}$ & $\begin{array}{l}\text { Concentrated morphine } \\
\text { sulphate } 20 \mathrm{mg} / \mathrm{ml} \text { oral } \\
\text { solution } 2-5 \mathrm{mg}(0.1-0.25 \mathrm{ml}) \\
\text { PRN. Apply buccally and rub } \\
\text { into cheek to take effect } \\
\text { Lorazepam } 0.5-1 \mathrm{mg} \text { QDS } \\
\text { Clonazepam } 0.5-1 \mathrm{mg} \text { QDS }\end{array}$ & $\begin{array}{l}\text { Morphine sulphate } 2.5- \\
\text { 5mg PRN } \\
\text { Midazolam 2.5-5mg PRN } \\
\text { if associated with } \\
\text { agitation or anxiety }\end{array}$ \\
\hline Agitation & $\begin{array}{l}\text { Lorazepam } 1 \mathrm{mg} \text { tablets: } 0.5 \text { - } \\
1 \mathrm{mg} \text { orally up to QDS } \\
\text { Levomepromazine } 12.5-25 \mathrm{mg} \\
\text { PRN QDS }\end{array}$ & $\begin{array}{l}\text { Lorazepam 0.5-1mg PRN } \\
\text { QDS } \\
\text { Clonazepam sub-lingual 0.5- } \\
\text { 1mg PRN QDS }\end{array}$ & $\begin{array}{l}\text { Midazolam 2.5-5mg PRN } \\
\text { Levomepromazine } 12.5- \\
25 \mathrm{mg} \text { PRN every } 4 \text { hours }\end{array}$ \\
\hline $\begin{array}{l}\text { Respiratory } \\
\text { secretions }\end{array}$ & & $\begin{array}{l}\text { Atropine eye drops } 1 \% 1-2 \\
\text { drops PRN QDS under the } \\
\text { tongue }\end{array}$ & $\begin{array}{l}\text { Glycopyrronium } 400 \mathrm{mcg} \\
\text { every } 4 \text { hours } \\
\text { Hyoscine butylbromide }\end{array}$ \\
\hline
\end{tabular}




\begin{tabular}{|l|l|l|l|}
\hline & & & $\begin{array}{l}\text { 20mg PRN every 2-4 } \\
\text { hours }\end{array}$ \\
\hline
\end{tabular}

' Screening: When someone is worried they might be infected; Place of Care: When deciding where a patient should go; Admitting: When a patient needs admission to hospital, or ICU; Counselling: When coping needs a boost, or emotions are running high; Deciding: Treatment escalation, goals of care, and do-not-resuscitate status; Resourcing: When limitations force a clinician to choose, and even ration; Anticipating: When a clinician is worrying about what might happen; Grieving: When someone dies 